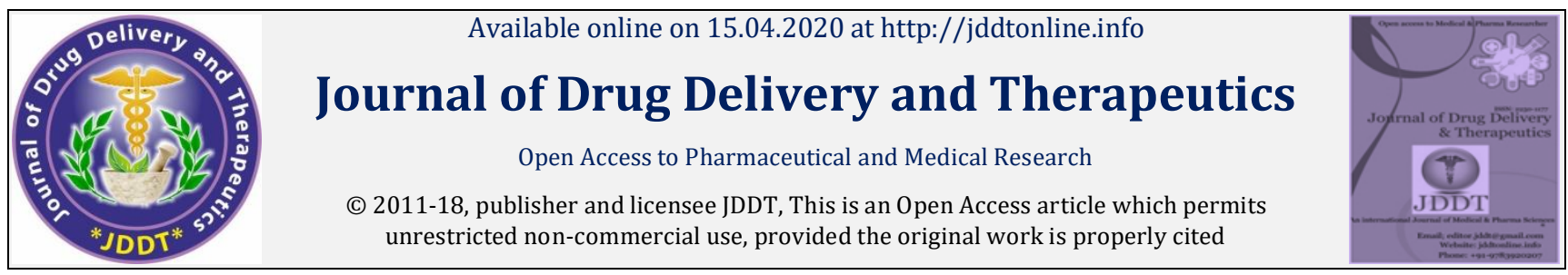

Open $\odot$ Access

Review Article

\title{
A Review on Drug of Pediatric Pulmonary Arterial Hypertension (PAH), their Chemistry and Pharmaceutical Dosage Forms
}

\author{
Dubey Rupal*, Pothuvan Umadoss, Bhamare Pankaj, Singh Alka, Upmanyu Neeraj \\ School of Pharmacy and Research, People's University, Bhanpur, 462037 Bhopal, M.P India
}

\begin{abstract}
Hypertension, specifically pulmonary hypertension, is a syndromethat can affect pediatric patients as well as adults. Pulmonary arterial hypertension (PAH) in pediatric patients, while rare, can be a lifethreateningcondition. There is no cure for PAH, only treatment options forchildren that are largely based on the results of adult studies. These therapies, however, can improve quality of life and survival. Treatment can be challenging because of the less approved medications and tolerable dosage forms for pediatric patients. Pediatric pulmonary arterial hypertension (PAH) shares common features of adult disease, but is associated with several additional disorders and challenges that require unique approaches. Current classes of medications primarily used to treat pediatric hypertension include phosphodiesterase inhibitors, endothelin receptor antagonists, and prostacyclins. Additional agents that may be utilized in selected pediatric patients include calcium channel blockers, anticoagulants, and inhalednitric oxide. Updates are provided on issues related to utility of the previous classification system to reflect pediatric-specific aetiologies and approaches to medical and interventional management of PAH. Also updates are provided about currently available drug substance and their details, pharmaceutical dosage forms and their details along with the mechanism of action, pharmacokinetics of the drug. These emerging data are improving the identification of appropriate targets for goal-oriented therapy inchildren. Such data will likely improve future advanced pharmaceutical dosage development and product design to enhance outcomes in pediatric PAH.
\end{abstract}

Keywords: Pulmonary arterial hypertension, pediatric hypertension, PAH

Article Info: Received 28 Jan 2020; Review Completed 09 March 2020; Accepted 18 March 2020; Available online 15 April 2020

\section{Cite this article as:}

Dubey R, Pothuvan U, Bhamare P, Singh A, Upmanyu N, A Review on Drug of Pediatric Pulmonary Arterial Hypertension (PAH), their Chemistry and Pharmaceutical Dosage Forms, Journal of Drug Delivery and Therapeutics. 2020; 10(2-s):156-170 http://dx.doi.org/10.22270/jddt.v10i2-s.3947

*Address for Correspondence:

Dr. Rupal Dubey, School of Pharmacy and Research, People's University, Bhopal (M.P)

\section{INTRODUCTION}

Pulmonary arterial hypertension is a rare blood vessel disorder of the lung in which the pressure in the pulmonary artery (the blood vessel that leads from the heart to the lungs) rises above normal levels. An increase of the number of smooth muscle cells in the walls of small lung arteries (a phenomenon called proliferation) that are remodeling the vessels, may lead to obstructions in the microcirculation, which will then lead to an increase in the blood pressure. Chronic thromboembolic pulmonary hypertension is a complication representing less than $1 \%$ of all cases of acute pulmonary embolism (the sudden blocking of a lung artery by a clot or foreign material which has been brought to its site by the blood current), which directly leads to pulmonary hypertension. Pulmonary arterial hypertension and chronic thromboembolic pulmonary hypertension are chronically debilitating and life-threatening

Pulmonary arterial hypertension (PAH) is still an important cause of morbidity and mortality in children. Despite recent developments in PAH-specific therapies, survival of patients with idiopathic PAH remains poor and appears to be worse in children compared with adults. During the past few years, treatment of PAH has undergone a remarkable evolution, which has led to the current approval by regulatory agencies of few drugs for adult patients from three main pharmacological groups (addressing three pathways) and four different routes ofadministration (oral, inhaled, subcutaneous andintravenous). In pediatric $\mathrm{PAH}$, blood low exiting the right side of the heart faces great erresistance due to increased muscle present in the walls of the lungs. The right ventricle then enlarges and thickens in response, which may lead to heart failure. However, emerging therapeutic strategies for adult $\mathrm{PAH}$, such as upfront oral combination therapy, have not been sufficiently studied in children ${ }^{1}$. Moreover, the complexity of pulmonary hypertensive vascular disease (PHVD) in children makes the selection of appropriate etherapies a great challenge far away from amere prescription of drugs. Therapy of pediatric $\mathrm{PH}$ is rather characterized by a complex strategy that includes the evaluation of severity and prognosis of the individual disease, the estimation of efficacy of different drugs, and their interaction and combination, as well as supportive and generalmeasures ${ }^{1-2}$.

Recently, additional surgical and interventional techniques for palliation of children with severe PAH have been 
reported. The beneficial effects ofthese strategies are mainly based on the relief of right ventricle (RV) pressure over load with a subsequent reduction of the interventricular septum shift to the left ventricle (LV), and improvement of systolic and diastolic LV performance. Although there is still a lack of data on effectiveness, formulation, pharmacokinetics, optimal dosing and treatment strategies, data are emerging that allow for the definition of appropriate treatment targets and goaloriented therapy in children. Nevertheless, children with PAH are currently treated with targeted PAH drugs with benefit. Conservative treatments overview for PAH have been provided and established in many articles ${ }^{1-14}$. Here with provided an overview of recent updates advance treatments and available pharmaceutical dosage forms.

\section{PHARMACOTHERAPY}

Many medications have been used and studied in the treatment of pediatric PAH. However, there are three medication classes that have been evaluated more thoroughly for their efficacy in pediatric $\mathrm{PH}$ treatment: phosphodiesterasetype 5 (PDE5) inhibitors, endothelin (ET) receptor antagonists, and prostacyclinagonists. Other medications used are calcium channel blockers, anticoagulants, and inhaled nitric oxide (iNO). Prior to initiation of targeted $\mathrm{PH}$ therapy, thepatient should be assessed for acute vasodilator responsiveness via cardiac catheterization; left-sided heart disease or pulmonary venous disease resultingin an anatomic obstruction should be excluded. Medication therapy is determined based on patient responsiveness to acute vasodilator testing (AVT; Figure 1) ${ }^{1}$. Acute vasodilator testing is used to assess the response of the pulmonary vascular bed to pulmonary-specific vasodilators. In children with IPAH or isolated pulmonary hypertensive vascular disease, response to AVT is defined as a decrease in mPAP of at least $10 \mathrm{mmHg}$ to $<40 \mathrm{mmHg}$, with normal or increased cardiacoutput and a decrease in mPAP 20\%; an increase or no change in cardiacindex; and a decrease or no change in pulmonary vascular resistance/systemicvascular resistance ratio ${ }^{1-2}$.

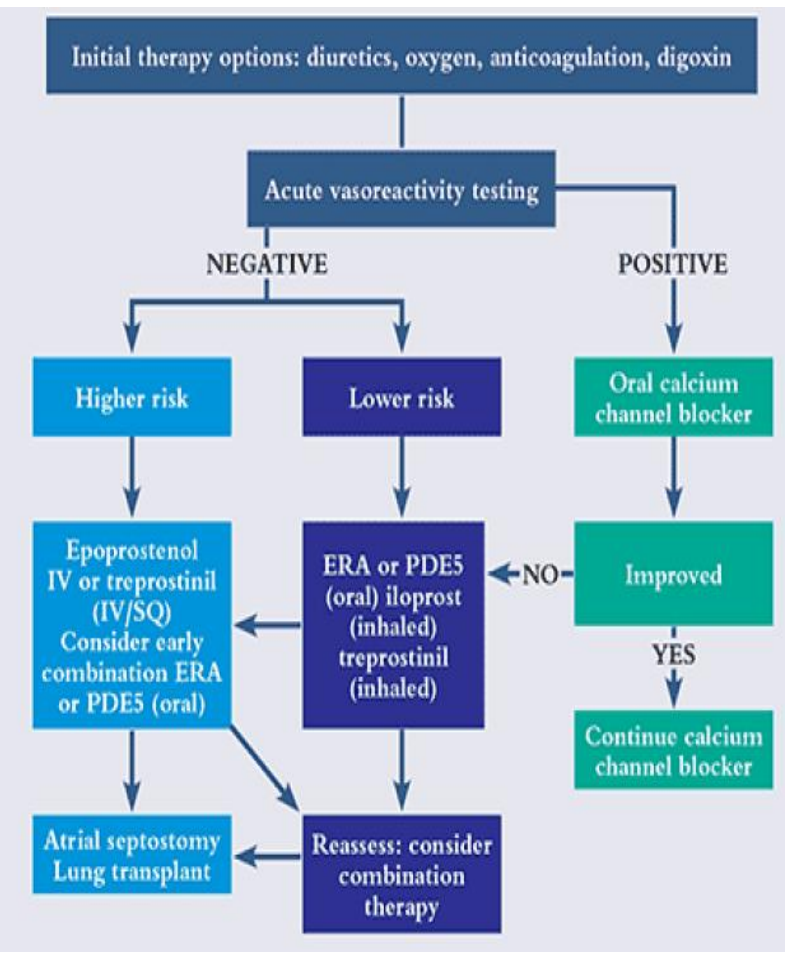

Figure 1- PAH: Pulmonary arterial hypertension; PDE5: Phosphdiesterase type 5; ERA: Endothelin receptor antagonist.

\section{Conservative Treatment:}

Therapies typically used for left heart failure have been alsoused for the treatment of patients with RV failure. Supportivetherapy may include oxygen, anticoagulants, diuretics, mineral corticoid receptor antagonists (spironolactone), digoxin. These measures are applied on an individual basis since the currently available studies provide either none or rather ambiguous/contradictory than valid data on most of these therapies in (adults and) children with $\mathrm{PH}^{1-12}$.

\section{CHEMISTRY OF PEDIATRIC PULMONARY ARTERIAL HYPERTENSION (PAH) DRUG}

\section{Endothelin-1 receptor antagonists}

\section{Bosentan:}

It belongs to a class of highly substituted pyrimidine derivatives, with no chiral centers. It is designated chemically as 4-tert-butyl-N-[6-(2-hydroxy-ethoxy)-5-(2-methoxyphenoxy)-[2,2']-bipyrimidin4-yl]-

benzenesulfonamidemonohydrate and has the following structural formula:<smiles>COc1ccccc1Oc1c(NS(=O)(=O)c2ccc(C(C)(C)C)cc2)nc(-c2ncccn2)nc1OCCO</smiles>

Figure 2 - Bosentan

Bosentan has a molecular weight of 569.64 and a molecular formula of $\mathrm{C}_{27} \mathrm{H}_{29} \mathrm{~N}_{5} \mathrm{O}_{6} \mathrm{~S} \bullet \mathrm{H}_{2} \mathrm{O}$. Bosentan is a white to yellowish powder. It is poorly soluble in water $(1.0 \mathrm{mg} / 100 \mathrm{~mL})$ and in aqueous solutions at low $\mathrm{pH}(0.1 \mathrm{mg} / 100 \mathrm{~mL}$ at $\mathrm{pH} 1.1$ and 4.0; $0.2 \mathrm{mg} / 100 \mathrm{~mL}$ at $\mathrm{pH} 5.0$ ). Solubility increases at higher $\mathrm{pH}$ values $(43 \mathrm{mg} / 100 \mathrm{~mL}$ at $\mathrm{pH} 7.5)$. In the solid state, bosentan is very stable, is not hygroscopic and is not light sensitive ${ }^{15}$.

\section{Ambrisentan:}

It is selective for the endothelin type-A (ETA) receptor. The chemical name of ambrisentan is (+)-(2S)-2-[(4,6dimethylpyrimidin-2-yl)oxy]-3-methoxy-3,3-

diphenylpropanoic acid. It has a molecular formula of C22H22N2O4 and a molecular weight of 378.42. It contains a single chiral center determined to be the (S) configuration and has the following structural formula:

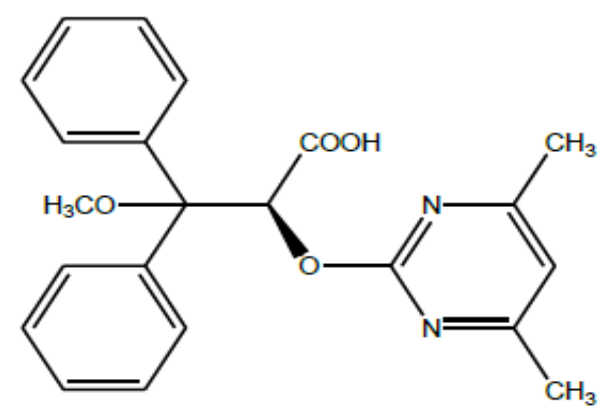

Figure 3 - Ambrisentan 
Ambrisentan is a white to off-white, crystalline solid. It is a carboxylic acid with a pKa of 4.0. Ambrisentan is practically insoluble in water and in aqueous solutions at low $\mathrm{pH}$. Solubility increases in aqueous solutions at higher $\mathrm{pH}$. In the solid state ambrisentan is very stable, is not hygroscopic, and is not light sensitive ${ }^{16}$.

\section{Macitentan:}

The chemical name of macitentan is $\mathrm{N}$-[5-(4-Bromophenyl)6-[2-[(5-bromo-2-pyrimidinyl)oxy]ethoxy]-4-pyrimidinyl]N'propylsulfamide. It has a molecular formula of $\mathrm{C}_{19} \mathrm{H}_{20} \mathrm{Br}_{2} \mathrm{~N}_{6} \mathrm{O}_{4} \mathrm{~S}$ and a molecular weight of 588.27. Macitentan is achiral and has the following structural formula:<smiles>CCCNS(=O)(=O)Nc1ncnc(OCCOc2ncc(Br)cn2)c1-c1ccc(Br)cc1</smiles>

Figure 4 - Macitentan

Macitentan is a crystalline powder that is insoluble in water. In the solid state macitentan is very stable, is not hygroscopic, and is not light sensitive ${ }^{17}$.

\section{Phosphodiesterase Inhibitors (PDE-5i)}

\section{Sildenafil :}

It is the citrate salt of sildenafil, a selective inhibitor of cyclic guanosine monophosphate(cGMP)-specific phosphordiesterase type-5 (PDE-5). Sildenafil citrate is designated chemically as 1-[[3-(6,7-dihydro-1-methyl-7-oxo-3-propyl$1 H$-pyrazolo [4,3-d] pyrimidin-5-yl)-4-ethoxyphenyl] sulfonyl]-4-methylpiperazine citrate and has the following structural formula:<smiles>CCCc1nn(C)c2c(=O)[nH]c(-c3cc(S(=O)(=O)N4CCN(C)CC4)ccc3OC)nc12</smiles>

Figure 5 - Sildenafil citrate

Sildenafil citrate is a white to off-white crystalline powder with a solubility of $3.5 \mathrm{mg} / \mathrm{mL}$ in water. Sildenafil citrate has the empirical formula $\mathrm{C}_{28} \mathrm{H}_{38} \mathrm{~N}_{6} \mathrm{O}_{11} \mathrm{~S}$ representing a molecular weight of 666.718 .

\section{Tadalafil :}

It is an oral treatment for pulmonary arterial hypertension, is a selective inhibitor of cyclic guanosine monophosphate (cGMP)-specific phosphodiesterase type 5 (PDE5). Tadalafil has the empirical formula $\mathrm{C}_{22} \mathrm{H}_{19} \mathrm{~N}_{3} \mathrm{O}_{4}$ representing a molecular weight of 389.41. The structural formula is:<smiles>CN1CC(=O)N2C(c3ccc4c(c3)OCO4)Cc3c([nH]c4ccccc34)C2(C)C1=O</smiles>

Figure 6 - Tadalafil

The chemical designation is pyrazino[1',2':1,6]pyrido[3,4b]indole-1,4-dione, 6-(1,3-benzodioxol-5-yl)2,3,6,7,12,12ahexahydro-2-methyl-, (6R,12aR)-. It is a crystalline solid that is practically insoluble in water and very slightly soluble in ethanol ${ }^{19}$.

\section{Guanylate cyclase stimulators}

\section{Riociguat:}

Riociguat is methyl 4,6-diamino-2-[1-(2-fluorobenzyl)-lHpyrazolo[3,4-b]pyridin-3-yl]-5-

pyrimidinyl(methyl)carbamate with the following structural formula:<smiles>COC(=O)N(C)c1c(N)nc(-c2nn(Cc3ccccc3F)c3ncccc23)nc1N</smiles>

Figure 7 - Riociguat

Riociguat is a white to yellowish, crystalline, non-hygroscopic substance with a molecular weight of $422.42 \mathrm{~g} / \mathrm{mol}$. It has the empirical formula of $\mathrm{C}_{20} \mathrm{H}_{19} \mathrm{FN}_{8} \mathrm{O}_{2}$. In solid form it is stable to temperature, light, and humidity 20.

The solubility at $25^{\circ} \mathrm{C}$ in water: $4 \mathrm{mg} / \mathrm{L}$, in ethanol: $800 \mathrm{mg} / \mathrm{L}$, in $0.1 \mathrm{HCl}(\mathrm{pH} \mathrm{1):} 250 \mathrm{mg} / \mathrm{L}$ and in buffer (phosphate) pH.7: 3 $\mathrm{mg} / \mathrm{L}$. In the $\mathrm{pH}$ range of 2 to 4 the solubility showed strong $\mathrm{pH}$-dependency. Solubility increases at lower $\mathrm{pH}$ values ${ }^{20}$.

\section{Vericiguat:}

Vericiguat is Methyl (4,6-diamino-2-(5-fluoro-1-(2fluorobenzyl)-1H-pyrazolo[3,4-b]pyridin-3-yl)pyrimidin-5yl)carbamate with the following structural formula:

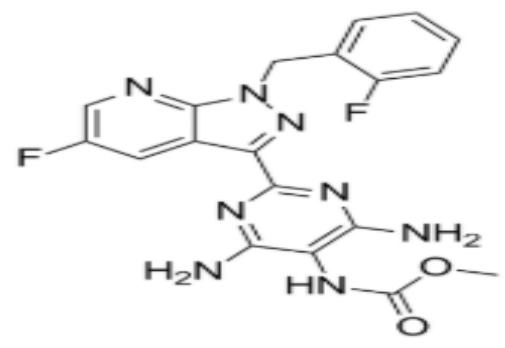

Figure 8 - Vericiguat 
It has the empirical formula of $\mathrm{C}_{19} \mathrm{H}_{16} \mathrm{~F}_{2} \mathrm{~N}_{8} \mathrm{O}_{2}$ with a molecular weight of $426.388 \mathrm{~g} / \mathrm{mol}$. In solid form it is stable to temperature, light, and humidity 21,22

Prostacyclin Analogues (Pca; Prostaglandin I Receptor Agonists; Ip Receptor Agonists)

\section{Epoprostenol :}

Epoprostenol (PGI2, PGX, prostacyclin), a metabolite of arachidonic acid, is a naturally occurring prostaglandin with potent vasodilatory activity and inhibitory activity of platelet aggregation.

Epoprostenol is $\quad(5 Z, 9 a, 11 a, 13 E, 15 S)-6,9$-epoxy-11,15dihydroxyprosta-5,13-dien-1-oic acid. Epoprostenol sodium has a molecular weight of 374.45 and a molecular formula of $\mathrm{C}_{20} \mathrm{H}_{31} \mathrm{NaO}_{5}$. The structural formula is:

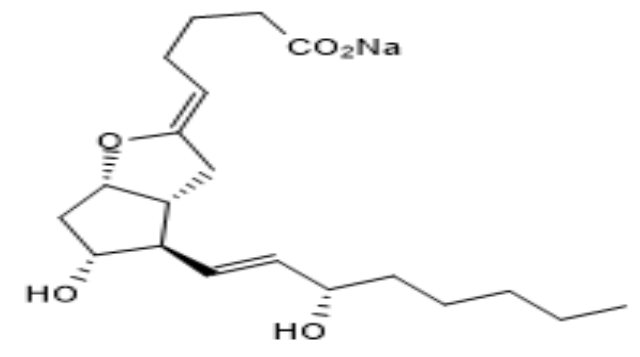

Figure 9 - Epoprostenol

Epoprostenol is a white to off-white lyophilized powder material. It is reconstituted with Sterile Water for Injection, USP, or Sodium Chloride $0.9 \%$ Injection, USP. The reconstituted solution of Epoprostenol has a $\mathrm{pH}$ ranging from 11 to 13 and is increasingly unstable at a lower $\mathrm{pH}^{23}$.

\section{Trepostinil :}

Treprostinil is $(1 R, 2 R, 3 \mathrm{a} S, 9 \mathrm{a} S)-[[2,3,3 \mathrm{a}, 4,9,9 \mathrm{a}$-hexahydro-2hydroxy-1-[(3S)-3-hydroxyoctyl] $1 H$-benz[f]inden-5yl]oxy]acetic acid. Treprostinil has a molecular weight of 390.52 and a molecular formula of $\mathrm{C}_{23} \mathrm{H}_{34} \mathrm{O}_{5}$. The structural formula of treprostinil is:

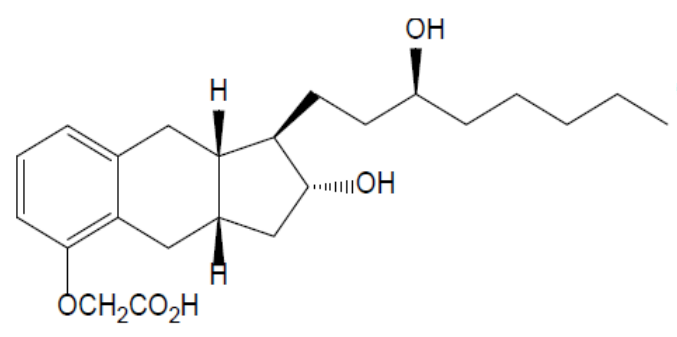

Figure 10 - Treprostinil

Treprostinil is chemically stable at room temperature and neutral $\mathrm{pH}$. Sterile Diluent for Remodulin is a high-pH ( $\mathrm{pH} \sim 10.4$ ) glycine diluent supplied in a $50 \mathrm{~mL}$ vial containing $50 \mathrm{~mL}$ of Sterile Diluent for Remodulin. Each vial contains 94 mg glycine, $73.3 \mathrm{mg}$ sodium chloride, sodium hydroxide (to adjust $\mathrm{pH}$ ), and water for injection 24 .

\section{Iloprost:}

The chemical name for iloprost is $(E)-(3 \mathrm{a} S, 4 R, 5 R, 6 \mathrm{a} S)$ hexahydro-5-hydroxy-4-[(E)-(3S,4RS)-3- hydroxy-4-methyl1-octen-6-ynyl]- $\Delta 2(1 H), \Delta$-pentalenevaleric acid. Iloprost consists of a mixture of the $4 \mathrm{R}$ and $4 \mathrm{~S}$ diastereomers at a ratio of approximately 53:47. The molecular formula of iloprost is $\mathrm{C} 22 \mathrm{H} 3204$. Its relative molecular weight is 360.49 . The structural formula is shown below:

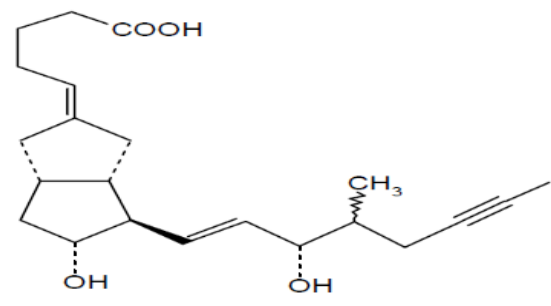

Figure 11 - Iloprost

Iloprost is an oily substance, which is soluble in methanol, ethanol, ethyl acetate, acetone and $\mathrm{pH} 7$ buffer, sparingly soluble in buffer $\mathrm{pH} 9$, and very slightly soluble in distilled water, buffer $\mathrm{pH} 3$, and buffer $\mathrm{pH} 525$.

\section{Beraprost :}

Beraprost is sodium $4-\{(1 \mathrm{R}, 2 \mathrm{R}, 3 \mathrm{aS}, 8 \mathrm{bS})-2$-Hydroxy-1[(1E,3S)-3-hydroxy-4-methyl-1-octen-6-yn-1-yl]-2,3,3a,8btetrahydro-1H-benzo[b]cyclopenta[d]furan-5-yl\}butanoic acid.

The Structural formula of beraprostis:

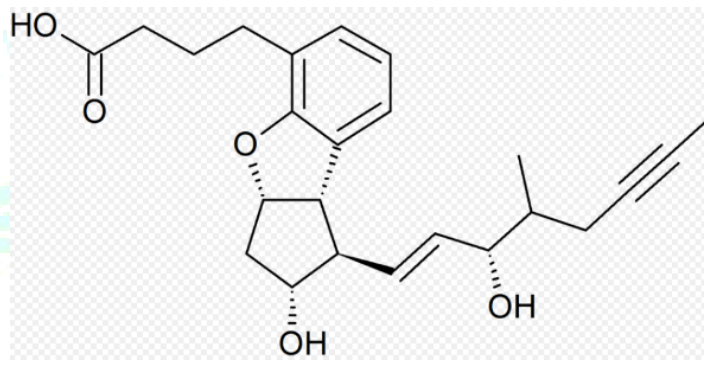

Figure 12 - Beraprost

Beraprost has a molecular weight of 398.492 and a molecular formula of $\mathrm{C}_{24} \mathrm{H}_{30} \mathrm{O}_{5}$. It is chemically stable at room temperature and neutral $\mathrm{pH}^{26,27}$.

\section{Selexipag :}

UPTRAVI (selexipag) is a selective non-prostanoid IP prostacyclin receptor agonist. The chemical name of selexipag is 2-\{4-[(5,6-diphenylpyrazin-2yl)(isopropyl)amino]butoxy $\}-\mathrm{N}$ (methylsulfonyl) acetamide. It has a molecular formula of $\mathrm{C}_{26} \mathrm{H}_{32} \mathrm{~N}_{4} \mathrm{O}_{4} \mathrm{~S}$ and a molecular weight of 496.62. Selexipag has the following structural formula:

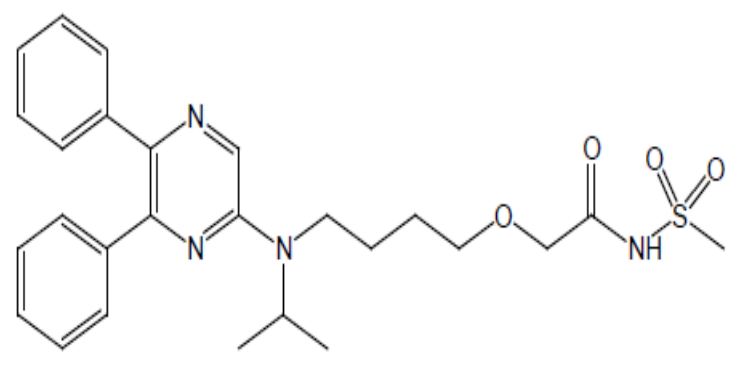

Figure 13 -Selexipag

Selexipag is a pale yellow crystalline powder that is practically insoluble in water. In the solid state selexipag is very stable, is not hygroscopic, and is not light sensitive ${ }^{28}$. 


\section{TREATMENT ALGORITHM FOR PEDIATRIC PULMONARY ARTERIAL HYPERTENSION (PAH)}

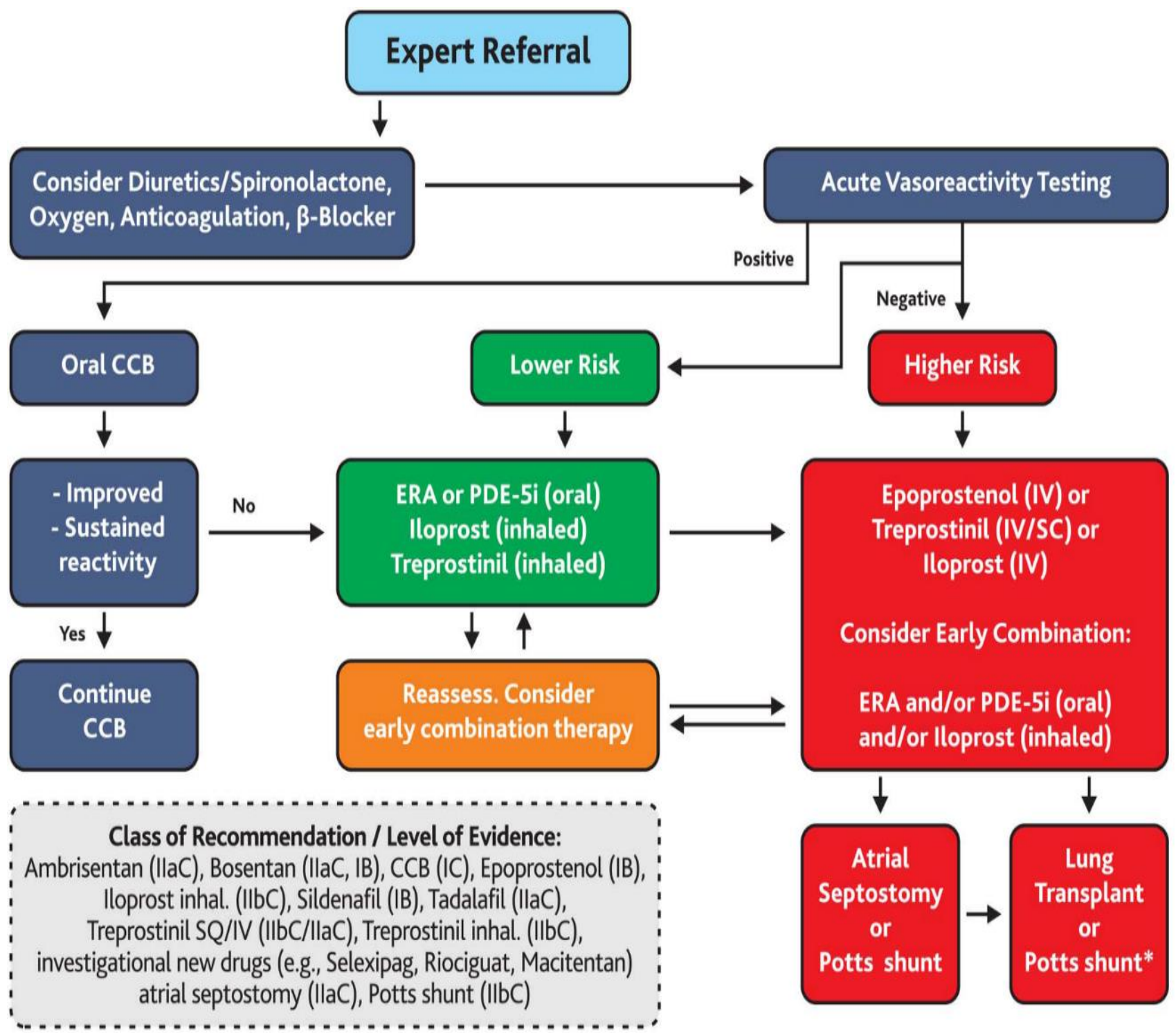

Figure 14 -Treatment algorithm for pediatric pulmonary arterial hypertension (PAH) 2. 
DOSAGE FORM AND MECHANISAM OF PEDIATRIC PULMONARY ARTERIAL HYPERTENSION (PAH) DRUG:

Table 1 - Endothelin-1 receptor antagonists

\begin{tabular}{|c|c|c|c|c|}
\hline $\begin{array}{l}\text { Drug } \\
\text { Name }\end{array}$ & Brand name & $\begin{array}{l}\text { Dosage } \\
\text { form }\end{array}$ & Excipients used & Mechanism of action \\
\hline \multicolumn{5}{|c|}{ Endothelin-1 receptor antagonists } \\
\hline \multirow[t]{2}{*}{ Bosentan $^{15}$} & $\begin{array}{l}\text { TRACLEER® } \\
\text { (bosentan) } \\
\text { tablets }\end{array}$ & $\begin{array}{l}\text { Immediate } \\
\text { release } \\
\text { tablets }\end{array}$ & $\begin{array}{l}\text { Bosentan is available as } 62.5 \mathrm{mg} \\
\text { and } 125 \mathrm{mg} \text { film-coated tablets for } \\
\text { oral administration, and contains } \\
\text { the following excipients: corn } \\
\text { starch, pregelatinized starch, } \\
\text { sodium starch glycolate, povidone, } \\
\text { glyceryl behenate, magnesium } \\
\text { stearate, } \\
\text { hydroxypropylmethylcellulose, } \\
\text { triacetin, talc, titanium dioxide, iron } \\
\text { oxide yellow, iron oxide red, and } \\
\text { ethylcellulose. Each Tracleer } 62.5 \\
\text { mg tablet contains } 64.54 \text { mg of } \\
\text { bosentan monohydrate, equivalent } \\
\text { to } 62.5 \text { mg of anhydrous bosentan. } \\
\text { Each Tracleer } 125 \text { mg tablet } \\
\text { contains } 129.08 \text { mg of bosentan } \\
\text { monohydrate, equivalent to } 125 \mathrm{mg} \\
\text { of anhydrous bosentan. }\end{array}$ & \multirow[t]{2}{*}{$\begin{array}{l}\text { Bosentan is a specific and competitive } \\
\text { antagonist at endothelin receptor types } \\
\text { ETA and ETB. Bosentan has a slightly } \\
\text { higher affinity for ETA receptors than for } \\
\text { ETB receptors. The clinical impact of dual } \\
\text { endothelin blockage isunknown. } \\
\text { Endothelin-1 (ET-1) is a neurohormone, } \\
\text { the effects of which are mediated by } \\
\text { binding to ETA and ETB receptors in the } \\
\text { endothelium and vascular smooth muscle. } \\
\text { ET-1 concentrations are elevated in plasma } \\
\text { and lung tissue of patients with PAH, } \\
\text { suggesting a pathogenic role for ET-1 in } \\
\text { this disease. }\end{array}$} \\
\hline & $\begin{array}{l}\text { TRACLEER® } \\
\text { (bosentan) } \\
\text { tablets for } \\
\text { oral } \\
\text { suspension }\end{array}$ & $\begin{array}{l}\text { Tablets for } \\
\text { suspension }\end{array}$ & $\begin{array}{l}\text { Bosentan is also available as a } 32 \\
\text { mg tablet for oral suspension and } \\
\text { contains the following excipients: } \\
\text { cellulose microcrystalline, calcium } \\
\text { hydrogen phosphate anhydrous, } \\
\text { croscarmellose sodium, silica } \\
\text { colloidal anhydrous, tartaric acid, } \\
\text { tuttifrutti flavor, aspartame (E951), } \\
\text { acesulfame potassium, and } \\
\text { magnesium stearate. Each } \\
\text { dispersible tablet contains } 1.87 \text { mg } \\
\text { of phenylalanine. Each dispersible } \\
\text { tablet contains } 33.045 \text { mg of } \\
\text { bosentan monohydrate, equivalent } \\
\text { to } 32 \text { mg anhydrous bosentan. }\end{array}$ & \\
\hline $\begin{array}{l}\text { Ambrisent } \\
\text { an } 16\end{array}$ & $\begin{array}{l}\text { Letairis } \\
\text { (ambrisentan } \\
\text { ) tablets }\end{array}$ & $\begin{array}{l}\text { Immediate } \\
\text { release } \\
\text { tablets }\end{array}$ & $\begin{array}{l}\text { Ambrisentan is available as } 5 \mathrm{mg} \\
\text { and } 10 \mathrm{mg} \text { film-coated tablets for } \\
\text { once daily oral administration. The } \\
\text { tablets include the following } \\
\text { inactive ingredients: } \\
\text { croscarmellose sodium, lactose } \\
\text { monohydrate, magnesium stearate } \\
\text { and microcrystalline cellulose. The } \\
\text { tablets are film-coated with a } \\
\text { coating material containing FD\&C } \\
\text { Red \#40 aluminum lake, lecithin, } \\
\text { polyethylene glycol, polyvinyl } \\
\text { alcohol, talc, and titanium dioxide. } \\
\text { Each square, pale pink Letairis } \\
\text { tablet contains } 5 \text { mg of } \\
\text { ambrisentan. Each oval, } \\
\text { deep pink Letairis tablet contains } \\
10 \text { mg of ambrisentan. }\end{array}$ & $\begin{array}{l}\text { Endothelin-1 (ET-1) is a potent autocrine } \\
\text { and paracrine peptide. Two receptor } \\
\text { subtypes, ETA and ETB, mediate the effects } \\
\text { of ET- } 1 \text { in the vascular smooth muscle and } \\
\text { endothelium. The primary actions of ETA } \\
\text { are vasoconstriction and cell proliferation, } \\
\text { while the predominant actions of ETB } \\
\text { arevasodilation, antiproliferation, and ET-1 } \\
\text { clearance. In patients with PAH, plasma ET- } \\
1 \text { concentrations are increased as much as } \\
10 \text {-fold and correlate. with increased mean } \\
\text { right atrial pressure and disease severity. } \\
\text { ET- } 1 \text { and ET- } 1 \text { mRNA concentrations are } \\
\text { increased as much as } 9 \text {-fold in the lung } \\
\text { tissue of patients with PAH, primarily in the } \\
\text { endothelium of pulmonary arteries. These } \\
\text { findings suggest that ET-1 may play a } \\
\text { critical role in the pathogenesis and } \\
\text { progression of PAH. Ambrisentan is a high- } \\
\text { affinity (Ki=0.011 nM) ETA receptor } \\
\text { antagonist with a high selectivity for the } \\
\text { ETA versus ETB receptor ( }>4000 \text {-fold). The } \\
\text { clinical impact of high selectivity for ETA is } \\
\text { not known. }\end{array}$ \\
\hline
\end{tabular}




\begin{tabular}{|c|c|c|c|c|}
\hline $\begin{array}{l}\text { Macitentan } \\
17\end{array}$ & $\begin{array}{l}\text { OPSUMIT } \\
\text { (macitentan) } \\
\text { tablets }\end{array}$ & $\begin{array}{l}\text { Immediate } \\
\text { release } \\
\text { tablets }\end{array}$ & $\begin{array}{l}\text { OPSUMIT is available as a } 10 \mathrm{mg} \\
\text { film-coated tablet for once daily } \\
\text { oral administration. The tablets } \\
\text { include the following inactive } \\
\text { ingredients: lactose monohydrate, } \\
\text { magnesium stearate, micro- } \\
\text { crystalline cellulose, polysorbate } \\
\text { 80, povidone, and sodium starch } \\
\text { glycolate Type A. The tablets are } \\
\text { film-coated with a coating material } \\
\text { containing polyvinyl alcohol, soya } \\
\text { lecithin, talc, titanium dioxide, and } \\
\text { xanthan gum. }\end{array}$ & $\begin{array}{l}\text { Endothelin (ET)-1 and its receptors (ETA } \\
\text { and ETB) mediate a variety of deleterious } \\
\text { effects, such as vasoconstriction, fibrosis, } \\
\text { proliferation, hypertrophy, and } \\
\text { inflammation. In disease conditions such as } \\
\text { PAH, the local ET system is upregulated } \\
\text { and is involved in vascular hypertrophy } \\
\text { and in organ damage. Macitentan is an } \\
\text { endothelin receptor antagonist that } \\
\text { prevents the binding of ET-1 to both ETA } \\
\text { and ETB receptors. Macitentan displays } \\
\text { high affinity and sustained occupancy of } \\
\text { the ET receptors in human pulmonary } \\
\text { arterial smooth muscle cells. One of the } \\
\text { metabolites of macitentan is also } \\
\text { pharmacologically active at the ET } \\
\text { receptors and is estimated to be about 20\% } \\
\text { as potent as the parent drug in vitro. }\end{array}$ \\
\hline
\end{tabular}

Table 2 - Phosphodiesterase inhibitors (PDE-5i)

\begin{tabular}{|c|c|c|c|c|}
\hline Drug Name & Brand name & Dosage form & Excipients used & Mechanism of action \\
\hline \multicolumn{5}{|c|}{ Phosphodiesterase inhibitors (PDE-5i) } \\
\hline \multirow[t]{3}{*}{ Sildenafil ${ }^{18}$} & $\begin{array}{l}\text { REVATIO } \\
\text { (sildenafil) } \\
\text { tablets }\end{array}$ & $\begin{array}{l}\text { Immediate } \\
\text { release tablets }\end{array}$ & $\begin{array}{l}\text { REVATIO is formulated as white, } \\
\text { film-coated round tablets with } 20 \\
\text { mg of sildenafil for oral } \\
\text { administration. In addition to the } \\
\text { active ingredient, sildenafil } \\
\text { citrate, each tablet contains the } \\
\text { following inactive ingredients: } \\
\text { microcrystalline cellulose, } \\
\text { anhydrous dibasic calcium } \\
\text { phosphate, croscarmellose } \\
\text { sodium, magnesium stearate, } \\
\text { hypromellose, titanium dioxide, } \\
\text { lactose monohydrate, and } \\
\text { triacetin. }\end{array}$ & \multirow{2}{*}{$\begin{array}{l}\text { Sildenafil is an inhibitor of cGMP } \\
\text { specific phosphodiesterase type-5 } \\
\text { (PDE-5) in the smooth muscle of } \\
\text { the pulmonary vasculature, where } \\
\text { PDE-5 is responsible for } \\
\text { degradation of cGMP. Sildenafil, } \\
\text { therefore, increases cGMP within } \\
\text { pulmonary vascular smooth muscle } \\
\text { cells resulting in relaxation. In } \\
\text { patients with PAH, this can lead to } \\
\text { vasodilation of the pulmonary } \\
\text { vascular bed and, to a lesser } \\
\text { degree, vasodilatation in the } \\
\text { systemic circulation. } \\
\text { Studies in vitro have shown that } \\
\text { sildenafil is selective for PDE-5. Its } \\
\text { effect is more potent on PDE-5 than } \\
\text { on other known } \\
\text { phosphodiesterases (10-fold for } \\
\text { PDE6, greater than 80-fold for } \\
\text { PDE1, greater than 700-fold for } \\
\text { PDE2, PDE3, PDE4, PDE7, PDE8, } \\
\text { PDE9, PDE10, and PDE11). The } \\
\text { approximately } 4,000 \text {-fold } \\
\text { selectivity for PDE-5 versus PDE3 } \\
\text { is important because PDE3 is } \\
\text { involved in control of cardiac } \\
\text { contractility. Sildenafil is only } \\
\text { about 10-fold as potent for PDE-5 } \\
\text { compared to PDE6, an enzyme } \\
\text { found in the retina and involved in } \\
\text { the photo transduction pathway of } \\
\text { the retina. This lower selectivity is } \\
\text { thought to be the basis for } \\
\text { abnormalities related to color } \\
\text { vision observed with higher doses }\end{array}$} \\
\hline & $\begin{array}{l}\text { REVATIO } \\
\text { (sildenafil) for } \\
\text { oral suspension }\end{array}$ & $\begin{array}{l}\text { Powder for } \\
\text { oral } \\
\text { suspension }\end{array}$ & $\begin{array}{l}\text { REVATIO is supplied in an amber } \\
\text { glass bottle as a white to off- } \\
\text { white powder providing a white } \\
\text { to off-white grape flavored oral } \\
\text { suspension when constituted. } \\
\text { Bottles containing } 32.27 \text { g } \\
\text { powder for oral suspension are } \\
\text { intended for constitution with } 90 \\
\text { mL water to produce an oral } \\
\text { suspension containing } 10 \mathrm{mg} / \mathrm{mL} \\
\text { sildenafil. In addition to the } \\
\text { bottle, a press-in bottle adapter } \\
\text { and an oral dosing syringe ( } 2 \mathrm{~mL}) \\
\text { are provided. The inactive } \\
\text { ingredients include sorbitol, } \\
\text { citric acid anhydrous, sucralose, } \\
\text { sodium citrate dihydrate, } \\
\text { xanthan gum, titanium dioxide, } \\
\text { sodium benzoate, colloidal silicon } \\
\text { dioxide anhydrous and grape } \\
\text { flavor }\end{array}$ & \\
\hline & $\begin{array}{l}\text { REVATIO } \\
\text { (sildenafil) } \\
\text { injection }\end{array}$ & $\begin{array}{l}\text { Intravenous } \\
\text { injection }\end{array}$ & $\begin{array}{l}\text { REVATIO is supplied as a clear, } \\
\text { colorless, sterile, ready to use } \\
\text { solution containing } 10 \mathrm{mg}(12.5 \\
\text { mL) of sildenafil. Each } \mathrm{mL} \text { of } \\
\text { solution contains } 1.124 \mathrm{mg} \\
\text { sildenafil citrate, } 50.5 \quad \mathrm{mg}\end{array}$ & $\begin{array}{l}\text { or plasma levels. } \\
\text { In addition to pulmonary vascular } \\
\text { smooth muscle and the corpus } \\
\text { cavernosum, PDE- } 5 \text { is also found in } \\
\text { other tissues including vascular } \\
\text { and visceral smooth muscle and in }\end{array}$ \\
\hline
\end{tabular}




\begin{tabular}{|c|c|c|c|c|}
\hline & & & dextrose and water for injection. & $\begin{array}{l}\text { platelets. The inhibition of PDE-5 in } \\
\text { these tissues by sildenafil may be } \\
\text { the basis for the enhanced platelet } \\
\text { anti-aggregatory activity of nitric } \\
\text { oxide observed in vitro, and the } \\
\text { mild peripheral arterial-venous } \\
\text { dilatation in vivo. }\end{array}$ \\
\hline Tadalafil $^{19}$ & $\begin{array}{l}\text { ADCIRCA } \\
\text { (tadalafil) } \\
\text { tablets }\end{array}$ & $\begin{array}{l}\text { Immediate } \\
\text { release tablets }\end{array}$ & 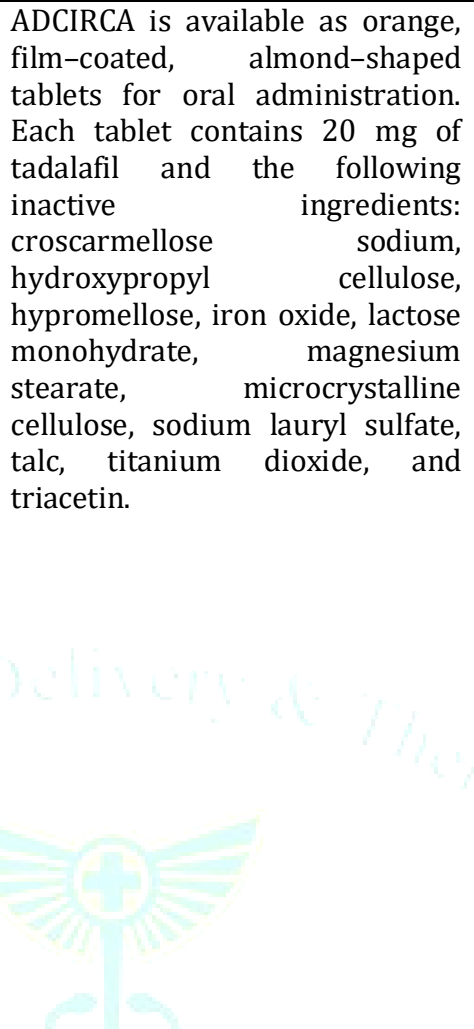 & $\begin{array}{l}\text { Tadalafil is an inhibitor of } \\
\text { phosphodiesterase type } 5 \text { (PDE5), } \\
\text { the enzyme responsible for the } \\
\text { degradation of cyclic guanosine } \\
\text { monophosphate (cGMP). } \\
\text { Pulmonary arterial hypertension is } \\
\text { associated with impaired release of } \\
\text { nitric oxide by the vascular } \\
\text { endothelium and consequent } \\
\text { reduction of cGMP concentrations } \\
\text { in the pulmonary vascular s mooth } \\
\text { muscle. PDE5 is the predominant } \\
\text { phosphodiesterase in the } \\
\text { pulmonary vasculature. Inhibition } \\
\text { of PDE5 by tadalafil increases the } \\
\text { concentrations of cGMP resulting in } \\
\text { relaxation of pulmonary vascular } \\
\text { smooth muscle cells and } \\
\text { vasodilation of the pulmonary } \\
\text { vascular ber ber } \\
\text { Studies in vitro have demonstrated } \\
\text { that tadalafil is a selective inhibitor } \\
\text { of PDE5. PDE5 is found in } \\
\text { pulmonary vascular smooth } \\
\text { muscle, visceral smooth muscle, } \\
\text { corpus cavernosum, skeletal } \\
\text { muscle, platelets, kidney, lung, } \\
\text { cerebellum, and pancreas. }\end{array}$ \\
\hline
\end{tabular}

Table 3 - Guanylate cyclase stimulators

\begin{tabular}{|c|c|c|c|c|}
\hline $\begin{array}{l}\text { Drug } \\
\text { Name }\end{array}$ & Brand name & $\begin{array}{l}\text { Dosage } \\
\text { form }\end{array}$ & Excipients used & Mechanisum of action \\
\hline \multicolumn{5}{|c|}{ Guanylate cyclase stimulators } \\
\hline Riociguat $^{20}$ & $\begin{array}{l}\text { Adempas } \\
\text { (riociguat) } \\
\text { tablets }\end{array}$ & $\begin{array}{l}\text { Immediate } \\
\text { release } \\
\text { tablets }\end{array}$ & $\begin{array}{l}\text { The inactive ingredients } \\
\text { are cellulose } \\
\text { microcrystalline, } \\
\text { crospovidone, } \\
\text { hypromellose } 5 \mathrm{cP} \text {, lactose } \\
\text { monohydrate, magnesium } \\
\text { stearate, sodium } \\
\text { laurylsulfate, } \\
\text { hydroxypropylcellulose, } \\
\text { hypromellose 3cP, } \\
\text { propylene glycol, titanium } \\
\text { dioxide. }\end{array}$ & $\begin{array}{l}\text { Riociguat is a stimulator of soluble guanylate cyclase } \\
\text { (sGC), an enzyme in the cardiopulmonary system and } \\
\text { the receptor for nitricoxide (NO). } \\
\text { When NO binds to sGC, the enzyme catalyzes synthesis } \\
\text { of the signaling molecule cyclic guanosine } \\
\text { monophosphate (cGMP). Intracellular cGMP plays an } \\
\text { important role in regulating processes that influence } \\
\text { vascular tone, proliferation, fibrosis andinflammation. } \\
\text { PAH is associated with endothelial dysfunction, } \\
\text { impaired synthesis of nitric oxide and insufficient } \\
\text { stimulation of the NO-sGC-cGMP pathway. Riociguat } \\
\text { has a dual mode of action. It sensitizes sGC to } \\
\text { endogenous NO by stabilizing the NO-sGC binding. } \\
\text { Riociguat also directly stimulates sGC via a different } \\
\text { binding site, independently of NO.Riociguat stimulates } \\
\text { the NO-sGC-cGMP pathway and leads to increased } \\
\text { generation of cGMP with subsequent vasodilation.The } \\
\text { active metabolite (M1) of riociguat is } 1 / 3 \text { to } 1 / 10 \text { as } \\
\text { potent as riociguat. }\end{array}$ \\
\hline
\end{tabular}


Table 4 - Prostacyclin analogues (PCA; prostaglandin I receptor agonists; IP receptor agonists)

\begin{tabular}{|c|c|c|c|c|}
\hline Drug Name & Brand name & Dosage form & Excipients used & Mechanism of action \\
\hline \multicolumn{5}{|c|}{ Prostacyclin analogues (PCA; prostaglandin I receptor agonists; IP receptor agonists) } \\
\hline Epoprostenol 23 & $\begin{array}{l}\text { VELETRI } \\
\text { (epoprostenol) } \\
\text { for Injection }\end{array}$ & $\begin{array}{l}\text { Infusion, } \\
\text { intravenous } \\
\text { infusion }\end{array}$ & $\begin{array}{l}\text { Epoprostenol sodium is the } \\
\text { sodium salt of epoprostenol, } \\
\text { formulated as a sterile } \\
\text { lyophilized powder for } \\
\text { intravenous } \\
\text { administration. Each vial of } \\
\text { VELETRI } \\
\text { epoprostenol contains } \\
\text { equivalent to either } 0.5 \mathrm{mg} \\
(500,000 \mathrm{ng} \text { ) or } 1.5 \mathrm{mg} \\
(1,500,000 \mathrm{ng} \text { ) epoprostenol, } \\
100 \mathrm{mg} \text { sucrose, and } 50 \mathrm{mg} \\
\text { arginine. Sodium hydroxide is } \\
\text { added to adjust pH. }\end{array}$ & $\begin{array}{l}\text { Epoprostenol has } 2 \text { major } \\
\text { pharmacological actions: (1) } \\
\text { direct vasodilation of pulmonary } \\
\text { and systemic arterial vascular } \\
\text { beds, and (2) inhibition of platelet } \\
\text { aggregation. }\end{array}$ \\
\hline Trepostinil $^{24}$ & $\begin{array}{l}\text { REMODULIN@ } \\
\text { (treprostinil) } \\
\text { Injection }\end{array}$ & $\begin{array}{l}\text { Injection, for } \\
\text { subcutaneous } \\
\text { or intravenous }\end{array}$ & $\begin{array}{l}\text { Sterile Diluent for Remodulin } \\
\text { is a high-pH (pH 10.4) glycine } \\
\text { diluent supplied in a } 50 \mathrm{~mL} \\
\text { vial containing } 50 \mathrm{~mL} \text { of } \\
\text { Sterile Diluent for Remodulin. } \\
\text { Each vial contains } 94 \mathrm{mg} \\
\text { glycine, } 73.3 \mathrm{mg} \text { sodium } \\
\text { chloride, sodium hydroxide (to } \\
\text { adjust pH), and water for } \\
\text { injection }\end{array}$ & $\begin{array}{l}\text { The major pharmacologic actions } \\
\text { of treprostinil are direct } \\
\text { vasodilation of pulmonary and } \\
\text { systemic arterial vascular beds, } \\
\text { and inhibition of platelet } \\
\text { aggregation. }\end{array}$ \\
\hline Iloprost 25 & $\begin{array}{l}\text { Ventavis } \\
\text { (iloprost) Solution }\end{array}$ & $\begin{array}{l}\text { Inhalation } \\
\text { Solution }\end{array}$ & 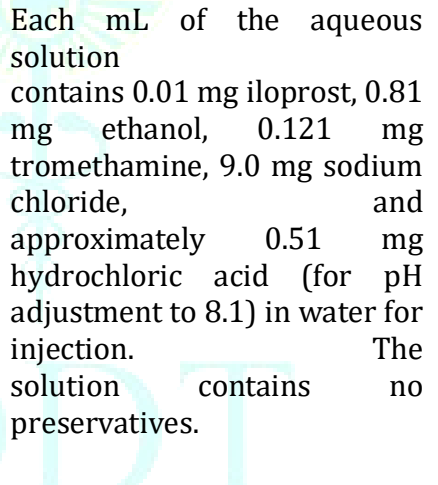 & $\begin{array}{l}\text { Iloprost is a synthetic analog of } \\
\text { prostacyclin PGI2. Iloprost dilates } \\
\text { systemic and pulmonary } \\
\text { arterial vascular beds. It also } \\
\text { affects platelet aggregation but } \\
\text { the relevance of this effect to the } \\
\text { treatment of pulmonary } \\
\text { hypertension is unknown. The } \\
\text { two diastereoisomers of iloprost } \\
\text { differ in their potency } \\
\text { in dilating blood vessels, with the } \\
4 S \text { isomer substantially more } \\
\text { potent than the 4R isomer. }\end{array}$ \\
\hline Selexipag28 & $\begin{array}{l}\text { UPTRAVI@ } \\
\text { (selexipag) } \\
\text { tablets. }\end{array}$ & $\begin{array}{l}\text { Immediate } \\
\text { release tablets }\end{array}$ & $\begin{array}{l}\text { The tablets include the } \\
\text { following inactive } \\
\text { ingredients:D-mannitol, corn } \\
\text { starch, low substituted HPC, } \\
\text { HPMC, and magnesium } \\
\text { stearate. The tablets are film } \\
\text { coated with a coating material } \\
\text { containing hypromellose, } \\
\text { propylene glycol, titanium } \\
\text { dioxide, carnauba wax along } \\
\text { with mixtures of iron oxide } \\
\text { red, iron oxide yellow or iron } \\
\text { oxide black. }\end{array}$ & $\begin{array}{l}\text { Selexipag is an oral prostacyclin } \\
\text { receptor (IP receptor) agonist } \\
\text { that is structurally distinct from } \\
\text { prostacyclin. Selexipag is } \\
\text { hydrolyzed by carboxylesterase } 1 \\
\text { to yield its active metabolite, } \\
\text { which is approximately } 37-\text {-fold as } \\
\text { potent as selexipag. Selexipag and } \\
\text { the active metabolite are selective } \\
\text { for the IP receptor versus other } \\
\text { prostanoid receptors (EP1-4, DP, } \\
\text { FP, and TP). }\end{array}$ \\
\hline
\end{tabular}


PHARMACOKINETICS OF PEDIATRIC PULMONARY ARTERIAL HYPERTENSION (PAH) DRUG:

Table 5 - ADME of Bosentan

\begin{tabular}{|c|c|c|c|c|}
\hline Drug Name & Absorption & Distribution & Metabolism & Elimination \\
\hline Bosentan $^{15}$ & $\begin{array}{l}\text { The absolute } \\
\text { bioavailability of } \\
\text { bosentan in normal } \\
\text { volunteers is about } \\
50 \% \text { and is } \\
\text { unaffected by food. }\end{array}$ & $\begin{array}{l}\text { After oral administration, } \\
\text { maximum plasma } \\
\text { concentrations of bosentan } \\
\text { are attained within } 3-5 \text { hours } \\
\text { and the terminal elimination } \\
\text { half-life is about } 5 \text { hours in } \\
\text { healthy adult subjects. The } \\
\text { exposure to bosentan after } \\
\text { intravenous and oral } \\
\text { administration is about twice } \\
\text { as high in adult patients with } \\
\text { PAH as it is in healthy adult } \\
\text { subjects. }\end{array}$ & $\begin{array}{l}\text { Bosentan has three } \\
\text { metabolites, one of } \\
\text { which is } \\
\text { pharmacologically active } \\
\text { and may contribute } \\
10 \%-20 \% \text { of the effect } \\
\text { of bosentan. Bosentan is } \\
\text { an inducer of CYP2C9 } \\
\text { and CYP3A and possibly } \\
\text { also of CYP2C19. }\end{array}$ & $\begin{array}{l}\text { Bosentan is eliminated by } \\
\text { biliary excretion following } \\
\text { metabolism in the liver. } \\
\text { Less than } 3 \% \text { of an } \\
\text { administered oral dose is } \\
\text { recovered in urine. Total } \\
\text { clearance after a single } \\
\text { intravenous dose is about } \\
4 \mathrm{~L} / \mathrm{h} \text { in patients with } \\
\text { PAH. }\end{array}$ \\
\hline
\end{tabular}

Table 6 - ADME of Ambrisentan

\begin{tabular}{|c|c|c|c|c|}
\hline Drug Name & Absorption & Distribution & Metabolism & Elimination \\
\hline Ambrisentan ${ }^{29}$ & $\begin{array}{l}\text { Ambrisentan was } \\
\text { well absorbed } \\
\text { following oral } \\
\text { administration. It } \\
\text { also showed high } \\
\text { absolute oral } \\
\text { bioavailability in } \\
\text { preclinical } \\
\text { species, } \\
\text { indicating that it } \\
\text { undergoes little } \\
\text { or no first pass } \\
\text { metabolism. }\end{array}$ & $\begin{array}{l}\text { In vitro results showed } \\
\text { that ambrisentan binds } \\
\text { to plasma proteins to a } \\
\text { higher extent in } \\
\text { humans }(98.9 \%) \text { than } \\
\text { in preclinical species } \\
(91.8-97.2 \%) \text {. In human } \\
\text { serum, it was apparent } \\
\text { that albumin was the } \\
\text { primary binding } \\
\text { protein in human } \\
\text { plasma. The results of a } \\
\text { rat tissue distribution } \\
\text { study with [14C]- } \\
\text { ambrisentan indicated } \\
\text { a wide distribution of } \\
\text { drug into tissues but } \\
\text { elimination occurred } \\
\text { relatively rapidly. }\end{array}$ & $\begin{array}{l}\text { Metabolism data obtained } \\
\text { following administration of } \\
\text { [14C]-ambrisentan showed that } \\
\text { metabolic } \\
\text { pathways for ambrisentan were } \\
\text { qualitatively similar in various } \\
\text { species. The metabolites } \\
\text { identified } \\
\text { include } 4,6 \text { dimethyl-2- } \\
\text { hydroxypryimidine, ambrisentan } \\
\text { glucuronide, } \\
\text { hydroxylatedambrisentan, 0- } \\
\text { demethylatedambrisentan, } \\
\text { dihydroxylatedambrisentan, } \\
\text { dihydroxylatedambrisentan } \\
\text { glucuronide, hydroxylated } \\
\text { ambrisentan glucuronide, and } \\
\text { Odemethylhydroxymethyl } \\
\text { ambrisentan. }\end{array}$ & $\begin{array}{l}\text { Based on disposition } \\
\text { studies conducted with } \\
{[14 C] \text {-ambrisentan, it }} \\
\text { was apparent that the } \\
\text { primary route of } \\
\text { excretion of drug- } \\
\text { related material was } \\
\text { faeces in all preclinical } \\
\text { species as well as in } \\
\text { humans. In } 12 / 44 \\
\text { humans, about } 66 \% \text { of } \\
\text { the dose was } \\
\text { recovered in faeces } \\
\text { and in animal species, } \\
\text { the faecal recovery } \\
\text { generally accounted } \\
\text { for } 69 \%-91 \% \text { of the } \\
\text { dose. Urinary } \\
\text { excretion was a minor } \\
\text { route of elimination in } \\
\text { both animal species (7- } \\
23 \% \text { as well as in } \\
\text { humans (23\%). }\end{array}$ \\
\hline
\end{tabular}


Table 7 - ADME of Macitentan

\begin{tabular}{|c|c|c|c|c|}
\hline Drug Name & Absorption & Distribution & Metabolism & Elimination \\
\hline Macitentan 30 & $\begin{array}{l}\text { The absolute } \\
\text { bioavailability of } \\
\text { macitentan could } \\
\text { not be established, } \\
\text { as the development } \\
\text { of an i.v. formulation } \\
\text { was not technically } \\
\text { feasible. Maximum } \\
\text { plasma } \\
\text { concentrations of } \\
\text { macitentan are } \\
\text { achieved about } 8 \\
\text { hours after } \\
\text { administration. }\end{array}$ & $\begin{array}{l}\text { Macitentan and ACT- } \\
132577 \text { are well distributed } \\
\text { into tissues as indicated by } \\
\text { an apparent volume of } \\
\text { distribution (Vss/F) of } \\
\text { approximately 50L and 40L } \\
\text { for macitentan and ACT- } \\
132577 \text {, respectively. } \\
\text { Macitentan and its active } \\
\text { metabolite are highly bound } \\
\text { to plasma proteins (>99\%), } \\
\text { primarily to albumin. }\end{array}$ & $\begin{array}{l}\text { Macitentan undergoes } \\
\text { biotransformation by } \\
\text { hydroxylation, with } \\
\text { CYP3A4 isoenzyme as } \\
\text { the major contributor. } \\
\text { The main metabolite is } \\
\text { ACT-132577 (active } \\
\text { M6), present at } \\
\text { approximately } 71 \% \text { of } \\
\text { total drug exposure in } \\
\text { plasma. No particularly } \\
\text { relevant consequences } \\
\text { of polymorphism in } \\
\text { CYP3A4 are expected. }\end{array}$ & $\begin{array}{l}\text { The major excretion route } \\
\text { of macitentan in humans, } \\
\text { in the form of metabolites, } \\
\text { is via urine, accounting for } \\
\text { about } 50 \% \text { of the dose, } \\
\text { while approximately } 24 \% \\
\text { of the administered dose } \\
\text { was recovered in faeces. } \\
\text { Neither unchanged } \\
\text { macitentan nor the active } \\
\text { metabolite ACT-132577 } \\
\text { were recovered in urine. }\end{array}$ \\
\hline
\end{tabular}

Table 8 - ADME of Sildenafil

\begin{tabular}{|c|c|c|c|c|}
\hline Drug Name & Absorption & Distribution & Metabolism & Elimination \\
\hline Sildenafil18 $^{18}$ & $\begin{array}{l}\text { REVATIO is rapidly } \\
\text { absorbed after oral } \\
\text { administration, } \\
\text { with a mean } \\
\text { absolute } \\
\text { bioavailability of } \\
41 \% \text { (25-63\%). } \\
\text { Maximum plasma } \\
\text { observed are } \\
\text { concentrations are } \\
\text { reached within } 30 \\
\text { to } 120 \text { minutes } \\
\text { (median } 60 \\
\text { minutes) of oral } \\
\text { dosing in the fasted } \\
\text { state. }\end{array}$ & $\begin{array}{l}\text { The mean steady state } \\
\text { volume of distribution } \\
\text { (Vss) for sildenafil is } \\
105 \text { L, indicating } \\
\text { distribution into the } \\
\text { tissues. Sildenafil and its } \\
\text { major circulating N- } \\
\text { desmethyl metabolite } \\
\text { are both approximately } \\
96 \% \text { bound to plasma } \\
\text { proteins. } \\
\text { binding is independent } \\
\text { of total } \\
\text { concentrations. } \\
\text { Bioequivalence } \\
\text { established between the } \\
20 \text { mg tablet and the } 10 \\
\text { mg/mL oral suspension } \\
\text { when administered as a } \\
20 \text { mg single oral dose } \\
\text { of sildenafil (as citrate). }\end{array}$ & $\begin{array}{l}\text { Sildenafil is reared } \\
\text { predominantly by the CYP3A } \\
\text { (major route) } r \text { and } \\
\text { cytochrome P450 } 2 \text { C9 } \\
\text { (CYP2C9, minor route) } \\
\text { hepatic microsomal } \\
\text { isoenzymes. The major } \\
\text { circulating metabolite results } \\
\text { from N-desmethylation of } \\
\text { sildenafil, and is, itself, } \\
\text { further metabolized. This } \\
\text { metabolite has a } \\
\text { phosphodiesterase selectivity } \\
\text { profile similar to sildenafil } \\
\text { and an in vitro potency for } \\
\text { PDE-5 approximately } 50 \% \text { of } \\
\text { the parent drug. In healthy } \\
\text { volunteers, plasma } \\
\text { concentrations of this } \\
\text { metabolite are approximately } \\
\text { 40\% of those seen for } \\
\text { sildenafil, so that the } \\
\text { metabolite accounts for } \\
\text { about 20\% of sildenafil's } \\
\text { pharmacologic effects. }\end{array}$ & $\begin{array}{l}\text { After either oral or } \\
\text { intravenous } \\
\text { administration, sildenafil is } \\
\text { excreted as metabolites } \\
\text { predominantly in the feces } \\
\text { (approximately } 80 \% \text { of the } \\
\text { administered oral dose) } \\
\text { and to a lesser extent in } \\
\text { the urine (approximately } \\
\text { 13\% of the administered } \\
\text { oral dose). } \\
\text { REVATIO Injection: The } \\
\text { pharmacokinetic profile of } \\
\text { REVATIO has been } \\
\text { characterized following } \\
\text { intravenous } \\
\text { administration. A } 10 \text { mg } \\
\text { dose of REVATIO Injection } \\
\text { is predicted to provide a } \\
\text { pharmacological effect of } \\
\text { sildenafil and its } \mathrm{N} \text { - } \\
\text { desmethyl metabolite } \\
\text { equivalent to that of a } 20 \\
\text { mg oral dose. }\end{array}$ \\
\hline
\end{tabular}


Table 9 - ADME of Tadalafil

\begin{tabular}{|c|c|c|c|c|}
\hline Drug Name & Absorption & Distribution & Metabolism & Elimination \\
\hline Tadalafil $19^{19}$ & $\begin{array}{l}\text { After single oral-dose } \\
\text { administration, the } \\
\text { maximum observed } \\
\text { plasma concentration } \\
\text { (Cmax) of tadalafil is } \\
\text { achieved between } 2 \\
\text { and } 8 \text { hours (median } \\
\text { time of } 4 \text { hours). } \\
\text { Absolute bioavailability } \\
\text { of tadalafil following } \\
\text { oral dosing has not } \\
\text { been determined. }\end{array}$ & $\begin{array}{l}\text { The mean apparent } \\
\text { volume of distribution } \\
\text { following oral } \\
\text { administration is } \\
\text { approximately } 77 \text { L, } \\
\text { indicating that tadalafil } \\
\text { is distributed into } \\
\text { tissues. At therapeutic } \\
\text { concentrations, } 94 \% \text { of } \\
\text { tadalafil in plasma is } \\
\text { bound to proteins. }\end{array}$ & $\begin{array}{l}\text { Tadalafil is predominantly } \\
\text { metabolized by CYP3A to a } \\
\text { catechol metabolite. The } \\
\text { catechol metabolite } \\
\text { undergoes extensive } \\
\text { methylation and } \\
\text { glucuronidation to form } \\
\text { the methylcatechol and } \\
\text { methylcatechol } \\
\text { glucuronide conjugate, } \\
\text { respectively. The major } \\
\text { circulating metabolite is } \\
\text { the methylcatechol } \\
\text { glucuronide. }\end{array}$ & $\begin{array}{l}\text { Following } 40 \mathrm{mg} \text {, the } \\
\text { mean oral clearance for } \\
\text { tadalafil is } 3.4 \mathrm{~L} / \mathrm{hr} \text { and } \\
\text { the mean terminal half- } \\
\text { life is } 15 \text { hours in healthy } \\
\text { subjects. In patients with } \\
\text { pulmonary hypertension } \\
\text { not receiving } \\
\text { concomitant bosentan, } \\
\text { the mean oral clearance } \\
\text { for tadalafil is } 1.6 \mathrm{~L} / \mathrm{hr} \text {, } \\
\text { and the mean terminal } \\
\text { half-life is } 35 \text { hours. . }\end{array}$ \\
\hline
\end{tabular}

Table 10 - ADME of Riociguat

\begin{tabular}{|c|c|c|c|c|}
\hline Drug Name & Absorption & Distribution & Metabolism & Elimination \\
\hline Riociguat 20 & $\begin{array}{l}\text { The absolute } \\
\text { bioavailability of } \\
\text { riociguat is about } \\
94 \% \text {. Peak plasma } \\
\text { riociguat } \\
\text { concentrations } \\
\text { were observed } \\
\text { within } 1.5 \text { hours } \\
\text { after tablet intake. } \\
\text { Food does not } \\
\text { affect the } \\
\text { bioavailability of } \\
\text { riociguat. }\end{array}$ & $\begin{array}{l}\text { The volume of } \\
\text { distribution at steady } \\
\text { state is approximately } \\
30 \text { L. Plasma protein } \\
\text { binding in humans is } \\
\text { approximately } 95 \% \text {, } \\
\text { with serum albumin and } \\
\alpha 1 \text {-acidic glycoprotein } \\
\text { being the main binding } \\
\text { components. Riociguat } \\
\text { is a substrate of P-gp } \\
\text { and BCRP. }\end{array}$ & $\begin{array}{l}\text { Riociguat is mainly cleared } \\
\text { by metabolism by CYP1A1, } \\
\text { CYP3A, CYP2C8 and CYP2J2. } \\
\text { Formation of the major active } \\
\text { metabolite, M1, is catalyzed } \\
\text { by CYP1A1, which is } \\
\text { inducible by polycyclic } \\
\text { aromatic hydrocarbons such } \\
\text { as those present in cigarette } \\
\text { smoke. M1 is further } \\
\text { metabolized to the inactive } \\
\text { N-glucuronide. Plasma } \\
\text { concentrations of M1 in } \\
\text { patients with PAH are about } \\
\text { half those for riociguat }\end{array}$ & $\begin{array}{l}\text { Following oral } \\
\text { administration of } \\
\text { radiolabeled riociguat in } \\
\text { healthy individuals, about } \\
40 \text { and } 53 \% \text { of the total } \\
\text { radioactivity was } \\
\text { recovered in urine and } \\
\text { feces, respectively. There } \\
\text { appears to be considerable } \\
\text { variability in the } \\
\text { proportion of metabolites } \\
\text { and unchanged riociguat } \\
\text { excreted, but metabolites } \\
\text { were the major } \\
\text { components of the dose } \\
\text { excreted in most } \\
\text { individuals. }\end{array}$ \\
\hline
\end{tabular}

Table 11 - ADME of Epoprostenol

\begin{tabular}{|c|c|c|c|c|}
\hline Drug Name & Absorption & Distribution & Metabolism & Elimination \\
\hline Epoprostenol23 & $\begin{array}{l}\text { The in vitro half- } \\
\text { life of } \\
\text { epoprostenol in } \\
\text { human blood at } \\
37^{\circ} \mathrm{C} \text { and pH } 7.4 \text { is } \\
\text { approximately } 6 \\
\text { minutes; } \\
\text { therefore, the in } \\
\text { vivo half-life of } \\
\text { epoprostenol in } \\
\text { humans } \\
\text { expected to be no } \\
\text { greater than } 6 \\
\text { minutes. }\end{array}$ & 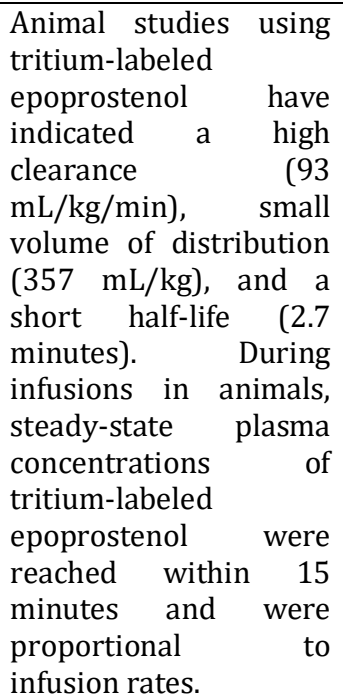 & $\begin{array}{l}\text { Tritium-labeled } \\
\text { epoprostenol has been } \\
\text { administered to humans in } \\
\text { order to identify the } \\
\text { metabolic products of } \\
\text { epoprostenol. Epoprostenol } \\
\text { is metabolized to } 2 \text { primary } \\
\text { metabolites: 6keto-PGF1 } \\
\text { (formed by spontaneous } \\
\text { degradation) and 6,15- } \\
\text { diketo-13,14-dihydro-PGF1 } \alpha \\
\text { (enzymatically formed), } \\
\text { both of which have } \\
\text { pharmacological activity } \\
\text { orders of magnitude less } \\
\text { than epoprostenol in animal } \\
\text { test systems }\end{array}$ & $\begin{array}{l}\text { The recovery } \\
\text { radioactivity in urine and } \\
\text { feces over a 1-week } \\
\text { period was } 82 \% \text { and } 4 \% \\
\text { of the administered dose, } \\
\text { respectively. Fourteen } \\
\text { additional minor } \\
\text { metabolites have been } \\
\text { isolated from urine, } \\
\text { indicating that } \\
\text { epoprostenol } \\
\text { extensively metabolized } \\
\text { in humans. }\end{array}$ \\
\hline
\end{tabular}


Table 12 - ADME of Trepostinil

\begin{tabular}{|c|c|c|c|c|}
\hline Drug Name & Absorption & Distribution & Metabolism & Elimination \\
\hline Trepostinil24 & $\begin{array}{l}\text { Trepostinil is } \\
\text { relatively rapidly and } \\
\text { completely absorbed } \\
\text { after subcutaneous } \\
\text { infusion, with an } \\
\text { absolute } \\
\text { bioavailability } \\
\text { approximating } \\
\text { 100\%. Steady-state } \\
\text { concentrations } \\
\text { occurred } \\
\text { approximately } 10 \\
\text { hours. } \\
\text { Concentrations in } \\
\text { patients treated with } \\
\text { an average dose of } \\
9.3 \text { ng/kg/min were } \\
\text { approximately 2,000 } \\
\text { ng/L. }\end{array}$ & $\begin{array}{l}\text { The volume of } \\
\text { distribution of the } \\
\text { drug in the central } \\
\text { compartment is } \\
\text { approximately } 14 \\
\text { L/70 kg ideal body } \\
\text { weight. Remodulin at } \\
\text { in vitro } \\
\text { concentrations well } \\
\text { above what is } \\
\text { clinically relevant } \\
\text { was } 91 \% \text { bound to } \\
\text { human plasma } \\
\text { protein. }\end{array}$ & $\begin{array}{l}\text { Treprostinil is substantially } \\
\text { metabolized by the liver, } \\
\text { primarily by CYP2C8. In a study } \\
\text { conducted in healthy } \\
\text { volunteers using [14C] } \\
\text { treprostinil, } 79 \% \text { and } 13 \% \text { of } \\
\text { the subcutaneous dose was } \\
\text { recovered in the urine and } \\
\text { feces, respectively, over } 10 \\
\text { days. Only } 4 \% \text { was excreted as } \\
\text { unchanged treprostinil in the } \\
\text { urine. Five metabolites were } \\
\text { detected in the urine, ranging } \\
\text { from } 10 \% \text { to } 16 \% \text { and } \\
\text { representing } 64 \% \text { of the dose } \\
\text { administered. }\end{array}$ & $\begin{array}{l}\text { The elimination of } \\
\text { treprostinil (following } \\
\text { subcutaneous } \\
\text { administration) is biphasic, } \\
\text { with a terminal elimination } \\
\text { half-life of approximately } 4 \\
\text { hours using a two- } \\
\text { compartment model. } \\
\text { Systemic clearance is } \\
\text { approximately } 30 \text { L/hour } \\
\text { for a } 70 \text { kg person. }\end{array}$ \\
\hline
\end{tabular}

Table 13 - ADME of Iloprost

\begin{tabular}{|c|c|c|c|c|}
\hline Drug Name & Absorption & Distribution & Metabolism & Elimination \\
\hline Iloprost 25 & $\begin{array}{l}\text { The absolute } \\
\text { bioavailability of } \\
\text { inhaled iloprost has } \\
\text { not been determined. }\end{array}$ & $\begin{array}{l}\text { Following } \\
\text { intravenous infusion, } \\
\text { the apparent steady- } \\
\text { state volume of } \\
\text { distribution was } 0.7 \\
\text { to } 0.8 \mathrm{~L} / \mathrm{kg} \text { in healthy } \\
\text { subjects. Iloprost is } \\
\text { approximately } 60 \% \\
\text { protein-bound, } \\
\text { mainly to albumin, } \\
\text { and this ratio is } \\
\text { concentration- } \\
\text { independent in the } \\
\text { range of } 30 \text { to } 3000 \\
\text { pg/mL. }\end{array}$ & $\begin{array}{l}\text { Clearance in normal subjects } \\
\text { was approximately } 20 \\
\mathrm{~mL} / \mathrm{min} / \mathrm{kg} \text {. Iloprost is } \\
\text { metabolized principally via } ß- \\
\text { oxidation of the carboxyl side } \\
\text { chain. The main metabolite is } \\
\text { tetranor-iloprost, which is } \\
\text { found in the urine in free and } \\
\text { conjugated form. In animal } \\
\text { experiments, tetranor- } \\
\text { iloprostwas pharmacologically } \\
\text { inactive. }\end{array}$ & $\begin{array}{l}\text { A mass-balance study } \\
\text { using intravenously and } \\
\text { orally administered [3H]- } \\
\text { iloprost in healthy subjects } \\
\text { (n=8) showed recovery of } \\
\text { total radioactivity over } 14 \\
\text { hours post-dose, was } 81 \% \text {, } \\
\text { with } 68 \% \text { and } 12 \% \\
\text { recoveries in urine and } \\
\text { feces, respectively }\end{array}$ \\
\hline
\end{tabular}

Table 14 - ADME of Selexipag

\begin{tabular}{|c|c|c|c|c|}
\hline Drug Name & Absorption & Distribution & Metabolism & Elimination \\
\hline Selexipag28 & $\begin{array}{l}\text { The absolute } \\
\text { bioavailability of } \\
\text { selexipag is } \\
\text { approximately } 49 \% \text { oral } \\
\text { Upon observed } \\
\text { administration, } \\
\text { maximum obs } \\
\text { plasma } \\
\text { concentrations of } \\
\text { selexipag and its } \\
\text { active metabolite are } \\
\text { reached within about } \\
\text { 1-3 hours and 3-4 } \\
\text { hours, respectively. }\end{array}$ & $\begin{array}{l}\text { The volume of } \\
\text { distribution of } \\
\text { selexipag at steady } \\
\text { state is } 11.7 \text { L. } \\
\text { Selexipag and its } \\
\text { active metabolite are } \\
\text { highly bound to } \\
\text { plasma proteins } \\
\text { (approximately } 99 \% \\
\text { in total and to the } \\
\text { same extent to } \\
\text { albumin and alpha1- } \\
\text { acid glycoprotein). }\end{array}$ & $\begin{array}{l}\text { Selexipag is hydrolyzed to its } \\
\text { active metabolite, (free } \\
\text { carboxylic acid) in the liver and } \\
\text { intestine by carboxylesterases. } \\
\text { Oxidative metabolism, } \\
\text { catalyzed mainly by CYP2C8 } \\
\text { and to a smaller extent by } \\
\text { CYP3A4, leads to the formation } \\
\text { of hydroxylated and } \\
\text { dealkylated products. UGT1A3 } \\
\text { and UGT2B7 are involved in the } \\
\text { glucuronidation of the active } \\
\text { metabolite. Except for the } \\
\text { active metabolite, none of the } \\
\text { circulating metabolites in } \\
\text { human plasma exceeds } 3 \% \text { of } \\
\text { the total drug-related material. }\end{array}$ & $\begin{array}{l}\text { Elimination of selexipag is } \\
\text { predominately via } \\
\text { metabolism with a mean } \\
\text { terminal half-life of } 0.8-2.5 \\
\text { hours. The terminal half- } \\
\text { life of the active metabolite } \\
\text { is } 6.2-13.5 \text { hours. There is } \\
\text { minimal accumulation of } \\
\text { the active metabolite upon } \\
\text { twice daily repeat } \\
\text { administration suggesting } \\
\text { that the effective half-life is } \\
\text { in the range of } 3-4 \text { hours. }\end{array}$ \\
\hline
\end{tabular}




\section{CONCLUSION:}

\section{This systematic review accomplishes 3 important objectives:}

(a) This underlines the need for effective therapies to treat the broad range of $\mathrm{PH}$ presentations in neonataland pediatric pulmonology, cardiology, and critical care.

(b) This intensely suggests that PDE5 inhibitors improve oxygenation and hemodynamic parameters in pediatric patients.

(c) This repeats the need for additional well-planned, prospective, comparative studies of the safety and efficacy of PDE inhibitors, other pulmonary vasodilators, and placebo controls in infants and children with $\mathrm{PH}^{53}$.

In the relatively small number of children studied, the survival rate was better in those children given combination therapy with epoprostenol and bosentan, with or without sildenafil, than in those on monotherapy. The indication for additional therapy was either an unsatisfactory response to initial therapy (epoprostenol or bosentan) or clinical deterioration. The concept of starting treatment with a single agent, preferably an oral drug, followed by the addition of a different agent(s) if necessary is supported by the benefit shown in several adult studies. Initiation of treatment with combination therapy has not been formally evaluated.

Transdermal drug delivery systems have been used as safe and effective drug delivery devices since 1981. A lot of progress has been done in the field of Transdermal Patches. Due to large advantages of the Transdermal Drug Delivery System, this system interests a lot of researchers. Many new researches are going on in the present day to incorporate newer drugs via this system. Transdermal dosage forms may provide clinicians an opportunity to offer more therapeutic options to their patients to optimize their care ${ }^{54}$.

Transdermal system for PAH treatment to the children is not established so far. Considering the fact of children's comfortability in order to intake solid and semisolid oral or intravenous injection, transdermal patch with PDE inhibitors would be a choice of dosage form for pediatric PAH. Hence more research should happened to establish transdermal patch with PDE inhibitors for pediatric PAH.

\section{REFERENCES:}

1. Ashley Buksa, Dima Huneidi. Pharmacotherapy of Pediatric Pulmonary Hypertension. US Pharm. 2017;42(5)(Specialty\&Oncologysuppl):28-31.

2. Georg Hansmann,ChristianApitz. Treatment of children with pulmonary hypertension. Expert consensus statement on the diagnosis and treatment of paediatric pulmonary Hypertension. The European Paediatric Pulmonary Vascular Disease Network, endorsed by ISHLT and DGPK.Heart. 2016; 102: 67-85

3. Dr. Andreas Rieth. What can be expected from current treatments for pulmonary hypertension?. European Society of Cardiology. 2017 Jan; 14(34)

4. Shahzad G. Raja and Shahbaz M. Raja. Treating pulmonary arterial hypertension: current treatments and future prospects. Therapeutic Advances in Chronic Disease. 2011; 2(6): 359-370

5. Michael D. McGoon. Upfront triple therapy for pulmonary arterial hypertension: is three a crowd or critical mass?. EurRespir J 2014; 43:1556-1559

6. Ghio S, Gavazzi A, Campana C, Inserra C, Klersy C, Sebastiani R, Arbustini E, Recusani F, Tavazzi L. Independent and additive prognostic value of right ventricular systolic function and pulmonary artery pressure in patients with chronic heart failure. J Am Coll Cardiol. 2001 Jan; 37(1):183-8.

7. McGoon MD, Benza RL, Escribano-Subias P, Jiang X, Miller DP, Peacock AJ, Pepke- Zaba J, Pulido T, Rich S, Rosenkranz S, Suissa S, Humbert M. Pulmonary arterial hypertension: epidemiology and registries. J Am CollCardiol. 2013 Dec 24;62.
8. Kanwar MK, Thenappan T, Vachiery JL. Update in treatment options in pulmonary hypertension. J Heart Lung Transplant. 2016 Jun; 35(6):695-703.

9. D'Alto M, Scognamiglio G, Dimopoulos K, Bossone E, Vizza D, Romeo E, Vonk- Noordergraaf A, Gaine S, Peacock A, Naeije R. Right heart and pulmonary vessels structure and function. Echocardiography. 2015 Jan; 32Suppl 1:S3-10.

10. Cogswell R, McGlothlin D, Kobashigawa E, Shaw R, De Marco T. Performance of the REVEAL model in WHO Group 2 to 5 pulmonary hypertension: application beyond pulmonary arterial hypertension. J Heart Lung Transplant. 2013 Mar; 32(3):293-8.

Haddad F, Doyle R, Murphy DJ, Hunt SA. Right ventricular function in cardiovascular disease, part II: pathophysiology, clinical importance, and management of right ventricular failure. Circulation. 2008 Apr 1;117 (13):1717-31.

11. Vonk-Noordegraaf A, Haddad F, Chin KM, Forfia PR, Kawut SM, Lumens J, Naeije R, Newman J, Oudiz RJ, Provencher S, Torbicki A, Voelkel NF, Hassoun PM. Right heart adaptation to pulmonary arterial hypertension: physiology and pathobiology. J Am Coll Cardiol. 2013 Dec 24; 62(25 Suppl):D22-33.

12. Benza RL, Gomberg-Maitland M, Miller DP, Frost A, Frantz RP Foreman AJ, Badesch DB, McGoon MD. The REVEAL Registry risk score calculator in patients newly diagnosed with pulmonary arterial hypertension. Chest. 2012 Feb;141(2):354-62.

13. McLaughlin VV, Gaine SP, Howard LS, Leuchte HH, Mathier MA, Mehta S, Palazzini M, Park MH, Tapson VF, Sitbon O. Treatment goals of pulmonary hypertension. J Am CollCardiol. 2013 Dec $24 ; 62$

14. TRACLEER $\AA$ (bosentan) tablets, for oral use, TRACLEER $\AA$ (bosentan) tablets for oral suspension Initial; U.S. Approval: 2001. Available at:

https://www.accessdata.fda.gov/drugsatfda_docs/label/2019/0 21290s039,209279s005lbl.pdf

15. Letairis (ambrisentan) tablets, for oral use; Initial U.S. Approval: 2007. Available at:

https://www.accessdata.fda.gov/drugsatfda_docs/label/2019/0 22081s041lbl.pdf

16. OPSUMIT(macitentan) tablets, for oral use; Initial U.S. Approval: 2013. Available at:

https://www.accessdata.fda.gov/drugsatfda_docs/label/2013/2 04410s000lbl.pdf

17. REVATIO (sildenafil) tablets, for oral use; REVATIO (sildenafil) for oral suspension; REVATIO (sildenafil) injection, for intravenous use; Initial U.S. Approval: 1998. Available at:

https://www.accessdata.fda.gov/drugsatfda_docs/label/2019/0 22473s012,203109s012lbl.pdf

18. ADCIRCA (tadalafil) tablets for oral administration; Initial U.S Approval: 2003. Available at:

https://www.accessdata.fda.gov/drugsatfda_docs/label/2017/0 22332s009lbl.pdf

19. Adempas (riociguat) tablets, for oral use; Initial U.S. Approval: 2013. Available at:

https://www.accessdata.fda.gov/drugsatfda_docs/label/2013/2 04819s000lbl.pdf

20. Markus Follmann,Jens Ackerstaff, Gorden Redlich, Frank Wunder, Dieter Lang, Armin Kern, Peter Fey, Nils Griebenow, Walter Kroh, Eva-Maria Becker-Pelster, Axel Kretschmer, Volker Geiss, Volkhart Li, Alexander Straub, Joachim Mittendorf, Rolf Jautelat, HartmutSchirok, Karl-Heinz Schlemmer, KlemensLustig, Michael Gerisch, Andreas Knorr, Hanna Tinel, Thomas Mondritzki, Hubert Trübel, Peter Sandner, and Johannes-Peter Stasch. Discovery of the Soluble Guanylate Cyclase Stimulator Vericiguat(BAY 1021189) for the Treatment of Chronic Heart Failure. Journal of Medicinal Chemistry. 2017 May; 60:5146-5161

21. Vericiguat Reduced the Risk of Heart Failure Hospitalization or Cardiovascular Death in Patients with Worsening Chronic Heart Failure with Reduced Ejection Fraction, Compared to Placebo When Added to Available Heart Failure Therapies. Merck and Bayer's Investigational Drug Vericiguat Meets Primary Endpoint in Phase 3 Study of Patients with Worsening Chronic Heart Failure. Published on Merck Newsroom Home. 2019 Nov; Source URL : https://www.mrknewsroom.com/news-release/researchand-development-news/merck-and-bayers-investigationaldrugvericiguat-meets-pr

22. VELETRI (epoprostenol) for Injection Initial U.S. Approval: 1995. Available at: 
https://www.accessdata.fda.gov/drugsatfda_docs/label/2018/0 22260s010lbl.pdf

23. REMODULIN® (treprostinil) Injection, for subcutaneous or intravenous use Initial U.S. Approval: May 2002. Available at: https://www.accessdata.fda.gov/drugsatfda_docs/label/2018/2 08276s000,021272s025lbl.pdf

24. Ventavis (iloprost) Inhalation Solution. Available at: https://www.accessdata.fda.gov/drugsatfda_docs/label/2019/0 21779s019lbl.pdf

25. Beraprost (sodium salt). Item No.18230. Product Information Cayman Chemical. www.caymanchem.com

26. Li Wang, MDa,b, Xinyi Zhu, MDa, Liang-Ping Zhao, MDa, Maosong Wang, MDa, Xiang Liu, MDa, Yuqi Chen, MDa, JianChang Chen, $\mathrm{PhDa}$, WeiTing $\mathrm{Xu}, \mathrm{MDa}$. Effect of beraprost on pulmonary hypertension due to left ventricular systolic dysfunction.Medicine.2019 March;98(16):1-6

27. UPTRAVI ${ }^{\circledR}$ (selexipag) tablets, for oral use: Initial U.S. Approval: 2015. Available at:

https://www.accessdata.fda.gov/drugsatfda_docs/label/2019/2 07947s007lbl.pdf

28. Assessment report for Volibris. Procedure No. EMEA/H/C/000839.EuropeanMedicines Agency Evaluation of Medicines for Human Use.Doc.Ref.:EMEA/123999/2008

29. Assessment report for Opsumit. Procedure No. EMEA/H/C/002697/0000. European Medicines Agency Evaluation of Medicines for Human Use. Doc.Ref.: EMA/CHMP/457699/2013

30. Schubert S, Peters B, Berger F. Interventional re-opening of a PDA for reverse Potts shunt circulation after ADOI implantation in a child. Catheter CardiovascInterv 2017;89: 133-136.

31. Esch JJ, Shah PB, Cockrill BA, etal.Transcatheter Potts shunt creation in patients with severe pulmonary arterial hypertension: initial clinical experience. J Heart Lung Transplant 2013;32: 381-387.

32. Salna M, VanBoxtel B, Rosenzweig EB, et al. Modified Potts shunt in an adult with idiopathic pulmonary arterial hypertension. Ann Am ThoracSoc 2017; 14: 607-609.

33. Adatia I, Haworth SG, Wegner M, et al. Clinical trials in neonates and children: report of the pulmonary hypertension academic research consortium pediatric advisory committee. PulmCirc 2013; 3: 252-266.

34. Ploegstra MJ, Ivy DD, Wheeler JG, et al. Growth in children with pulmonary arterial hypertension: a longitudinal retrospective multiregistry study. Lancet Respir Med 2016; 4: 281-290.

35. Tissot C, Beghetti M. Review of inhaled iloprost for the control of pulmonary artery hypertension in children. Vasc Health Risk Manag 2009; 5: 325-331.

36. Krishnan U, Takatsuki S, Ivy DD, et al. Effectiveness and safety of inhaled treprostinil for the treatment of pulmonary arterial hypertension in children. Am J Cardiol 2012; 110: 1704-1709.

37. Lammers AE, Hislop AA, Flynn Y, et al. Epoprostenol treatment in children with severe pulmonary hypertension. Heart 2007; 93 739-743.

38. Rosenzweig EB, Kerstein D, Barst RJ. Long-term prostacyclin for pulmonary hypertension with associated congenital heart defects. Circulation 1999; 99: 1858-1865.

39. Siehr SL, Ivy DD, Miller-Reed K, et al. Children with pulmonary arterial hypertension and prostanoid therapy: long-term hemodynamics. J Heart Lung Transplant 2013; 32: 546-552.

40. Levy M, Del Cerro MJ, Nadaud S, et al. Safety, efficacy and management of subcutaneous treprostinil infusions in the treatment of severe pediatric pulmonary hypertension. Int J Cardiol 2018; 264: 153-157.

41. Levy M, Celermajer DS, Bourges-Petit E, et al. Add-on therapy with subcutaneous treprostinil for refractory pediatric pulmonary hypertension. J Pediatr 2011; 158: 584-588.

42. Rosenzweig EB. Tadalafil for the treatment of pulmonary arterial hypertension. Expert OpinPharmacother 2010; 11: 127-132.

43. Takatsuki S, Calderbank M, Ivy DD. Initial experience with tadalafil in pediatric pulmonary arterial hypertension PediatrCardiol 2012; 33: 683-688.

44. Limsuwan A, Wanitkul S, Khosithset A, et al. Aerosolized iloprost for postoperative pulmonary hypertensive crisis in children with congenital heart disease. Int J Cardiol 2008; 129: 333-338.

45. Ivy DD, Doran AK, Smith KJ, et al. Short- and long-term effects of inhaled iloprost therapy in children with pulmonary arterial hypertension. J Am CollCardiol 2008; 51: 161-169.
46. Melnick L, Barst RJ, Rowan CA, et al. Effectiveness of transition from intravenous epoprostenol to oral/ inhaled targeted pulmonary arterial hypertension therapy in pediatric idiopathic and familial pulmonary arterial hypertension. Am J Cardiol 2010; 105: 1485-1489.

47. Barst RJ, Beghetti $\mathrm{M}$, Pulido $\mathrm{T}$, et al; STARTS-2 Investigators.STARTS-2: long-term survival with oral sildenafi 1 monotherapy in treatment-naive pediatric pulmonary arterial hypertension. Circulation. 2014;129(19):1914-1923

48. Uslu S, Kumtepe S, Bulbul A, Comert S, Bolat F, Nuhoglu A. A comparison of magnesium sulphate and sildenafi $l$ in the treatment of the newborns with persistent pulmonary hypertension: a randomized controlled trial. J Trop Pediatr. 2011;57(4):245-250

49. Vargas-Origel A, Gomez-Rodriguez G, Aldana-Valenzuela C, VelaHuerta MM, Alarcon-Santos SB, AmadoR-Licona N. The use of sildenafil inpersistent pulmonary hypertension of the newborn. Am J Perinatol. 2010;27(3):225-230

50. Peiravian F, Amirghofran AA, Borzouee M, Ajami GH, Sabri MR, Kolaee $S$. Oral sildenafil to control pulmonary hypertension after congenital heart surgery. Asian CardiovascThorac Ann.2007;15(2):113-117

51. Baquero H, Soliz A, Neira F, Venegas ME, Sola A. Oral sildenafil in infants with persistent pulmonary hypertension of the newborn. Pediatrics. 2006;117(4):1077-1083

52. Kahveci H, Yilmaz O, Avsar UZ, et al. Oral sildenafil and inhaled iloprost in the treatment of pulmonary hypertension of the newborn. Pediatr Pulmonol. 2014;49(12):1205-1213

53. Chinwe Unegbu, Corina Noje, John D. Coulson, Jodi B. Segal, MPH, Lewis Romer. Pulmonary Hypertension Therapy and a Systematic Review of Efficacy and Safety of PDE-5 Inhibitors. Journal of the American Academy of Pediatrics. 2017 March; 139(3): 1-21

54. Mark R. Prausnitz and Robert Langer. Transdermal drug delivery. Nat Biotechnol. 2008 Nov; 26(11): 1261-1268. 